\title{
Optimization and Partial Characterization of Bacillus Protease Isolated from Soil and Agro-industrial Wastes
}

\author{
Daniel Yimer Legesse \\ Ethiopian Institute of Agricultural Research (EIAR), Holeta Agricultural Research Center (HARC), National Agricultural Biotechnology \\ Laboratory, Microbial Biotechnology Research, Addis Ababa, Ethiopia
}

Email address:

daniyoo23@gmail.com

\section{To cite this article:}

Daniel Yimer Legesse. Optimization and Partial Characterization of Bacillus Protease Isolated from Soil and Agro-industrial Wastes. International Journal of Nutrition and Food Sciences. Vol. 6, No. 1, 2017, pp. 31-38. doi: 10.11648/j.ijnfs.20170601.16

Received: November 3, 2016; Accepted: December 2, 2016; Published: January 20, 2017

\begin{abstract}
Proteases from microbial sources possess almost all the characteristics desired for their biotechnological applications. This study was conducted with the aim of screening for potent protease-producing bacteria from soils and agroindustrial wastes, determining optimal production conditions and partially characterizing the stability of the protease with regards to some physicochemical parameters. Thus, the optimum protease production time for these 3 isolates, was found to be $36 \mathrm{~h}$ isolated from industrial waste, manure, and soil, respectively. The optimum temperature of protease production for both PS-3 and PI-3 was $40^{\circ} \mathrm{C}$. Whereas $37^{\circ} \mathrm{C}$ was the optimum for PM-1. In all cases, $\mathrm{pH} 7$ was the optimum for production of protease. Furthermore, $0.6 \mathrm{M} \mathrm{NaCl}$ concentration was found to give better protease activity than the media containing $\mathrm{no} \mathrm{NaCl}$ in all 3 isolates,. Among the metallic ions, media containing $\mathrm{Mn}^{2+}$ performed better than $\mathrm{Cu}^{2+}, \mathrm{Mg}^{2+}, \mathrm{Fe}^{2+}$, and $\mathrm{Zn}^{2+}$ for $P S-3$ and PM-1, whereas $\mathrm{Mg}^{2+}$ was the best for PI-3. Studies on the effect of $\mathrm{pH}$ on the stability of protease enzymes revealed that the crude enzyme had a maximum stability at $\mathrm{pH} 9.0$ for isolates PS-3 (36.5 and $26.5 \mathrm{U} / \mathrm{ml}$ ) and PI-3 (29.7 and $22.7 \mathrm{U} / \mathrm{ml})$, while for isolate PM-1 maximum stability was achieved at $\mathrm{pH} 8$ with values corresponding to 18.2 and $15.5 \mathrm{U} / \mathrm{ml}$, respectively. These proteases are also stable at $75^{\circ} \mathrm{C}$ for PS-3 $(42.9$ and $33.4 \mathrm{U} / \mathrm{ml})$ and PI-3 $(46.8$ and $42.1 \mathrm{U} / \mathrm{ml})$, while they showed maximum activity and stability at $50^{\circ} \mathrm{C}$ for PM- $1(22.5$ and $23.1 \mathrm{U} / \mathrm{ml}$, respectively). Pre-incubation at temperatures above $70^{\circ} \mathrm{C}$ for PS-3 and PI-3 and $50^{\circ} \mathrm{C}$ for PM-1 resulted in reduction of enzyme activity, indicating that the proteases are thermally unstable. Studies on the effect of concentration of divalent ions revealed that both the activity and stability of protease were better in $1 \mathrm{mM}$ than in $5 \mathrm{mM}$ concentration. Furthermore, evaluation of some agro-industrial wastes as potential substrates for protease production indicated that wheat bran was better for PS-3 $(4.3 \mathrm{U} / \mathrm{ml})$ and PM-1 $(3.0 \mathrm{U} / \mathrm{ml})$, whereas human hair was better for PI-3 $(3.9 \mathrm{U} / \mathrm{ml})$. Since protease was produced from readily available complex substrates and agro-industrial wastes, the 3 Bacillus species appear to have substantial potential for application in various proteolytic processes. Thus, identification of the 3 Bacillus isolates at a molecular level and purification as well as detailed characterization of the types of the proteases are recommended for effective utilization in different area of applications.
\end{abstract}

Keywords: Bacillus sp., Enzyme Assay, Gelatin Hydrolysis, Protease, Agro-industrial Wastes

\section{Introduction}

The opportunities to use proteins as ingredients in food and feed products are often limited by the properties of the proteins. One of the methods used to modify these properties is the hydrolysis of the proteins to smaller peptides. Modification of the molecular structure of food proteins with enzymes is an attractive way of improving the functional and nutritional properties of these proteins $[1,2]$. Protein structure is modified to improve solubility, emulsification, gelling and foaming properties. Chemical modification is not desirable for food applications because of the harsh reaction conditions, non-specific chemical reagents and the difficulties of removing residual reagents from the final product. Enzymes, however, provide several advantages, including fast reaction rates, mild conditions and (most importantly) high specificity.

Enzymes are highly efficient and environmentally friendly protein catalysts synthesized by living systems. They have significant advantages over the chemical catalysts, of which 
the most important ones are: specificity, high catalytic activity, ability to work at moderate as well as extreme temperatures [3]. Hydrolytic reactions of proteins utilize a very large and complex group of enzymes, which differ in properties such as substrate specificity, active site and catalytic mechanism, $\mathrm{pH}$ and temperature optima and stability profile. The specificity of proteolytic enzymes is governed by the nature of the amino acid and other functional groups (aromatic or aliphatic or sulphurcontaining) close to the bond being hydrolysed [4].

Proteolytic enzymes are the most important industrial enzymes, representing worldwide sale about $60 \%$ of the total enzyme market $[5,6]$. Proteases are obtained from plant, animal and microbial sources. In the last 30 years different classes of proteases of commercial importance have been produced from microbial, animal and plant sources and implemented for enormous applications in a range of processes which take advantage of the unique physical and catalytic properties of individual proteolytic enzyme types. Subsequently, using the native sources, a number of proteases have been designed by genetic engineering to produce a wide range of enzymes that have become available on a larger scale and increased the scope of enzyme technology globally [7, 4].

Although proteases are widespread in nature, microbes serve as a preferred source of these enzymes and account for around two-thirds of commercial protease production worldwide. Proteases are widely distributed in microbial populations viz. bacteria, actinomycetes, viruses and fungi. Microorganisms elaborate a large array of proteases, which are intracellular and/or extracelular. Intracellular proteases are important for various cellular and metabolic processes, such as sporulation and differentiation, protein turnover, maturation of enzymes and hormones and maintenance of the cellular protein pool. Whereas, extracellular proteases are important for the hydrolysis of proteins in cell-free environments and enable the cell to absorb and utilize hydrolytic products [8].

Although there are many microbial sources available for producing proteases, only a few are recognized as commercial producers [8].

Bacterial proteases have come to represent one of the largest classes of industrial enzymes, accounting for $40 \%$ of the total worldwide sale of enzymes [9]. Of these, strains of Bacillus sp. dominate the industrial sector [8]. Proteases can be classified based on the $\mathrm{pH}$ of their optimal activities, they are referred to as acidic, neutral, or alkaline proteases $[9,10,4]$.

Most studies focused on screening proteases with a criterion set only to increase the activity level. In this regard, selection of the right bacterial isolates plays a key role in the production of high yield desirable proteases. On the other hand, it is a well-known fact that extracellular protease production in microorganisms is greatly influenced by media components, especially carbon and nitrogen sources, Temperature, $\mathrm{pH}$ and metallic ions. Though the production of these enzymes has been improved significantly by the utilization of hyper-producing strains of fungi and bacteria and genetically modified microbes as well, efforts are still being done to find newer sources of enzymes, better production techniques and novel applications of these enzymes in unexplored fields [4].

Even though there are diverse ecological niches in Ethiopia, very little attempt has been made to isolate industrially important and potent protease producing bacteria from the environment. So far, from the few reports available in Ethiopia. Thus, to maximize the benefits from our biological resources, it is highly desirable to strengthen such efforts and search for new proteases with novel properties from as many different sources as possible. Thus, the general objective of this study was, to isolate Bacillus species from soil and various agro-industrial wastes and optimize and characterize the conditions of laboratory-scale production of extracellular proteases.

\section{Material and Methods}

\subsection{Sample Collection}

Samples of soil and agro-industrial wastes (manure, kitchen waste, soil contaminated with slaughtered animal hide waste and leather industry waste) were collected using sterile polyethylene bags and brought to the laboratory.

\subsection{Qualitative Screening}

\subsubsection{Gelatin Hydrolysis Test}

The diluted samples were plated onto Gelatin agar plates containing peptone $(0.1 \% \mathrm{w} / \mathrm{v}), \mathrm{NaCl}(0.5 \% \mathrm{w} / \mathrm{v})$, agar $(2.0 \%$ $\mathrm{w} / \mathrm{v})$, and gelatin $(1 \% \mathrm{w} / \mathrm{v})$ at $\mathrm{pH}-7.0$. Plates were incubated at $37^{\circ} \mathrm{C}$ for 24 hours. Selection of isolates for further experimental studies were depending upon the diameter of the zone of clearance [11].

\subsubsection{Casein Hydrolysis Test}

Those colonies that were able to hydrolyze gelatin were further inoculated on nutrient agar containing $1 \%$ casein $(\mathrm{w} / \mathrm{v})$ and incubated at $37^{\circ} \mathrm{C}$ for 24 hours. Casein hydrolysis was visualized by the application of $30 \%$ trichloroacetic acid on the agar surface. A transparent halo around the bacterial growth was considered as being a positive reaction (12).

\subsection{Seed Culture Medium}

For enzyme production, bacterial cells from a $24 \mathrm{~h}$ aged culture were inoculated in to $100 \mathrm{ml}$ Erlenmeyer flasks containing $50 \mathrm{ml}$ of sterile inoculation medium containing glucose, $\mathrm{CaCl}_{2}, \mathrm{~K}_{2} \mathrm{HPO}_{4}$ and $\mathrm{MgSO}_{4}$ and casein as substrate. The composition of the inoculum medium was the same as that of the medium described for culture maintenance. The cultures were grown at $37^{\circ} \mathrm{C}$ for $24 \mathrm{~h}$. After incubation for 24 $\mathrm{h}, 2 \%(\mathrm{v} / \mathrm{v})$ of the culture was used to inoculate the production medium [13].

\subsection{Production Medium}

The culture medium $(50 \mathrm{ml}$ sterile broth) containing (g/l): 
glucose (1.0), peptone (10.0), yeast extracts (0.2), casein (10), $\mathrm{CaCl}_{2}(0.1), \mathrm{K}_{2} \mathrm{HPO}_{4}(0.5)$ and $\mathrm{MgSO}_{4}$ (0.1) was inoculated with $1 \mathrm{ml}$ of pure culture of the selected isolate and incubated at different conditions to optimize protease producing isolates.

\subsection{Biochemical Characterization}

A loop-full of sample from an overnight culture was streaked on to nutrient agar plate and incubated for $24 \mathrm{~h}$ at $37^{\circ} \mathrm{C}$. From the resulting agar culture, a loop-full of culture was again added to media containing different biochemicals and incubated at appropriate temperature for 24 hours. Presence or absence of changes in the media was recorded as positive and negative, respectively, and the results were interpreted as per the information provided by Bergey's Manual of Determinative Bacteriology [14] used for identification of bacterial isolates.

\subsection{Enzyme Assay}

Protease activity was determined using casein as a substrate as described by [15]. The reaction mixture contained a total volume of $2 \mathrm{ml}$ which in turn was composed of $1 \mathrm{ml}$ of $1 \%$ casein in $50 \mathrm{mM}$ sodium phosphate buffer $(\mathrm{pH}$ 7) and $1 \mathrm{ml}$ enzyme solution. After $20 \mathrm{~min}$ of incubation at $37^{\circ} \mathrm{C}$, the reaction was terminated by adding $2 \mathrm{ml}$ of $10 \%$ trichloroacetic acid (TCA) and again incubated at $37^{\circ} \mathrm{C}$ for $20 \mathrm{~min}$. After separation of the un-reacted casein precipitate by centrifugation at $10000 \mathrm{rpm}$ for $15 \mathrm{~min}, 0.5 \mathrm{ml}$ of clear supernatant was mixed with $2.5 \mathrm{ml}$ of $0.5 \mathrm{M} \mathrm{Na}_{2} \mathrm{CO}_{3}$ and 0.5 $\mathrm{ml}$ of $1 \mathrm{~N}$ Folin-Ciocalteau's phenol reagent. After incubation for $20 \mathrm{~min}$ at $37^{\circ} \mathrm{C}$, absorbance was measured at $660 \mathrm{~nm}$ against a reagent blank. One unit of protease activity is defined as the amount of enzyme that releases $1 \mu \mathrm{g}$ amino acid equivalent to tyrosine per minute under the standard assay conditions $[14,6]$.

$$
\text { Units } / \mathrm{ml}=\frac{\mu \text { mole of tyrosine } \mathrm{x} \text { reaction vol }}{\text { Sample vol } \mathrm{x} \text { reaction time } \mathrm{x} \text { vol assay }}
$$

Source: [16].

\subsection{Optimization of the Growth Conditions for Production of Protease}

Time, temperature and $\mathrm{pH}$ were determined by incubating the cultures at $37^{\circ} \mathrm{C}$ for times $24-60 \mathrm{~h}$, temperatures of 30,37 , 40,45 and $50^{\circ} \mathrm{C}$ for $36 \mathrm{~h}$ and adjusting the $\mathrm{pH}$ of the growth medium to $\mathrm{pH} 5.0,6.0,7.0,8.0$, and 9.0 , the protease activity was determined as mentioned before $[17,6$.

\subsubsection{Optimization of the Effect of $\mathrm{NaCl}$ Concentration on the Production of Protease}

$\mathrm{NaCl}$ was added at various concentrations, i.e. 0.0, 0.2, $0.4,0.6$ and $0.8 \mathrm{M}$, into the protease production medium and assay for crude enzyme (protease) activity was carried out incubating the culture for $36 \mathrm{~h}$ [18]. Effect of concentration of $\mathrm{NaCl}$ was studded by considering results of the protease activity, higher activity of protease was due to higher production of protease.

\subsubsection{Optimization of the Effect of Metallic Ions on the Production of Protease}

The effect of metallic ions was studied by growing the bacteria in the presence of chemicals containing divalent cations such as $\mathrm{CuSO}_{4}, \mathrm{MgCl}_{2}, \mathrm{FeSO}_{4}, \mathrm{MnCl}_{2}$, and $\mathrm{ZnCl}_{2}$. The culture was incubated for $36 \mathrm{~h}$ and filtrates in each case were subsequently analyzed for protease activity and compared with one another. Effect of each metallic ion was studded depending on the production of protease after analyzed protease activity.

\subsection{Characterization of Protease}

\subsubsection{Effect of pH on the Stability of Protease}

The crude protease was incubated at different $\mathrm{pH}$ values such as $5,6,7,8,9$, and 10 with phosphate buffer $(\mathrm{pH} 7.0)$. The effect on the stability was studied by pre-incubating for 12 hours and determining the remaining activity following the standard protease assay procedures described above [19].

\subsubsection{Effect of Temperature on the Stability of Protease}

This experiment was performed by incubating protease at different temperatures viz.: 30, 40, 50, 60, 65, 70, 75 and $80^{\circ} \mathrm{C}$. The effect on the stability was studied by preincubating for 12 hours and determining the remaining activity following the standard protease assay procedures described by [19].

\subsubsection{Effect of Divalent Ions on the Activity of Protease}

The effects of $\mathrm{Ca}^{2+}, \mathrm{Mg}^{2+}, \mathrm{Mn}^{2+}, \mathrm{Fe}^{2+}$ and $\mathrm{Zn}^{2+}$ ions on crude protease extract were investigated by adding these cations to the reaction mixture to final concentrations of 1 and $5 \mathrm{mM}$. Enzyme activities in all cases were measured under conditions of optimum $\mathrm{pH}$ and temperature required for activity.

\subsection{Use of Agro-industrial Wastes as Substrates for Protease Production}

To find out the suitability of agro-industrial-based waste as substrate for protease production, different substrates viz., noug cake, sesame cake, animal hair and wheat bran were tested by replacing nitrogen source for isolates in the growth media under SmF. The enzyme activity was measured after 36 hour growth for determination of protease production [20].

\subsection{Data Analysis}

All data presented here in this study were the average of at least two measurements and all graphical and numerical data values generated by using Microsoft Excel 2007.

\section{Results and Discussion}

\subsection{Screening to Optimize Protease Producing Isolates}

Proteolytic bacterial isolates were detected when the serially diluted samples were plated on media containing 
gelatin. The sample source and the diameter of zone of hydrolysis for each proteolytic isolate are shown in Table 1. In the present study, spore forming bacteria were targeted and identified as members of the genus Bacillus on the basis of their morphological and biochemical characteristics. 18 different spore- forming bacteria were isolated, each of them were Bacillus. The Bacillus isolates were then screened for protease production by using the agar plates containing gelatin $(1 \% \mathrm{w} / \mathrm{v})$ at $37^{\circ} \mathrm{C}$ for $24 \mathrm{~h}$.

The proteolytic activity was detected by the presence of a clear zone of hydrolysis on gelatin agar. As can be seen from Table 1, among the Bacillus isolates obtained through screening, PS-3, PM-1 and PI-3 showed the largest zone of hydrolysis and hence were subsequently selected from within their respective groups as the best protease producers. These 3 isolates were then picked from the mother plate and further streaked on casein $(1 \% \mathrm{w} / \mathrm{v})$ agar, where they displayed a clear zone of hydrolysis.

Table 1. Diameter of zone of hydrolysis on gelatin media for bacterial isolates obtained from three samples.

\begin{tabular}{lll}
\hline Sample source & Isolate & $\begin{array}{l}\text { Diameter of the zone } \\
\text { of hydrolysis }(\mathbf{m m})\end{array}$ \\
\hline & PM-1 & 27 \\
& PM-2 & 22 \\
Manure & PM-3 & 15 \\
& PM-4 & 12 \\
& PM-5 & 9 \\
& PM-6 & 8 \\
& PI-1 & 10 \\
& PI-2 & 15 \\
Industrial waste & PI-3 & 26 \\
& PI-4 & 20 \\
& PI-5 & 7 \\
& PI-6 & 5 \\
& PS-1 & 10 \\
Soil contaminated with & PS-2 & 15 \\
slaughtered animal hide waste & PS-3 & 25 \\
& PS-4 & 18 \\
& PS-5 & 6 \\
& PS-6 & 5 \\
\hline
\end{tabular}

\subsection{Biochemical Characterization of the Bacterial Isolates}

The isolates PS-3, PM-1 and PI-3 were identified as sporeforming bacterial species that belong to the genus Bacillus based on the Bergey's manual Classification of determinative Bacteriology.

\subsection{Enzyme Assay}

Quantitative determination of the proteolytic activity revealed that the 3 bacterial isolates produce proteases at varying levels. As part of the preliminary selection criteria, protease activity for each of the three isolates was determined by growing the cultures for $36 \mathrm{~h}$ at $37^{\circ} \mathrm{C}$ and $\mathrm{pH} 7$. The results showed that PI-3, PS-3 and PM-1 yielded a protease activity of $6.5 \mathrm{U} / \mathrm{ml}, 6.4 \mathrm{U} / \mathrm{ml}$ and $4.4 \mathrm{U} / \mathrm{ml}$ with a total protein content of 93.92, 93.06, and $65.29 \mu \mathrm{g} / \mathrm{ml}$, respectively (Table 2). Microbial proteases are produced from high yielding strains including species of Bacillus sp., Alcaligenes faecalis, Pseudomonas fluorescens and Aeromonas hydrophilia grown under submerged culture conditions. Among these, Bacillus is the most important group of bacteria that is widely used in the enzyme industry and is particularly known for producing effective proteolytic enzymes [15].

Table 2. Quantitative assay for protease enzyme production by the three selected isolates.

\begin{tabular}{llll}
\hline No & Enzyme producers & $\begin{array}{l}\text { Protease assay } \\
(\mathbf{U} / \mathbf{m l} / \mathbf{m i n})\end{array}$ & $\begin{array}{l}\text { Total protein } \\
\text { content }(\boldsymbol{\mu g} / \mathbf{m l})\end{array}$ \\
\hline 1 & PS-3 & 6.4 & 93.06 \\
2 & PM-1 & 4.4 & 65.29 \\
3 & PI-3 & 6.5 & 93.92 \\
\hline
\end{tabular}

\subsection{Tyrosine Standard Curve}

To prepare the standard curve $0.5 \mathrm{M}$ of $\mathrm{Na}_{2} \mathrm{CO}_{3}, 50 \mathrm{mM}$ of sodium phosphate buffer, $\mathrm{pH} 7.00$, diluted $1 \mathrm{~N}$ Folin reagent and $10 \mathrm{mg} / \mathrm{ml}$ of Tyrosine stock solution were used. A required amount of buffer and Tyrosine were added in each test tube except blank. Then $2.5 \mathrm{ml}$ of $0.5 \mathrm{M} \mathrm{Na} \mathrm{CO}_{3}$ was added in each test tube including blank. After $500 \mu$ of $1 \mathrm{~N}$ Folin reagent was added in each test tube including blank, the solution was mixed immediately and kept for $30 \mathrm{~min}$ at room temperature. Finally, the optical density (OD) was measured at $660 \mathrm{~nm}$ using spectrophotometer and the standard curve was plotted (Figure 1).

Based on the above procedures and experimental results (data not shown), the following standard curve was obtained. So, to determine the protease activity of the 3 isolates, the following calibration curve was used with the regression coefficient of $\mathrm{R}^{2}=0.996$.

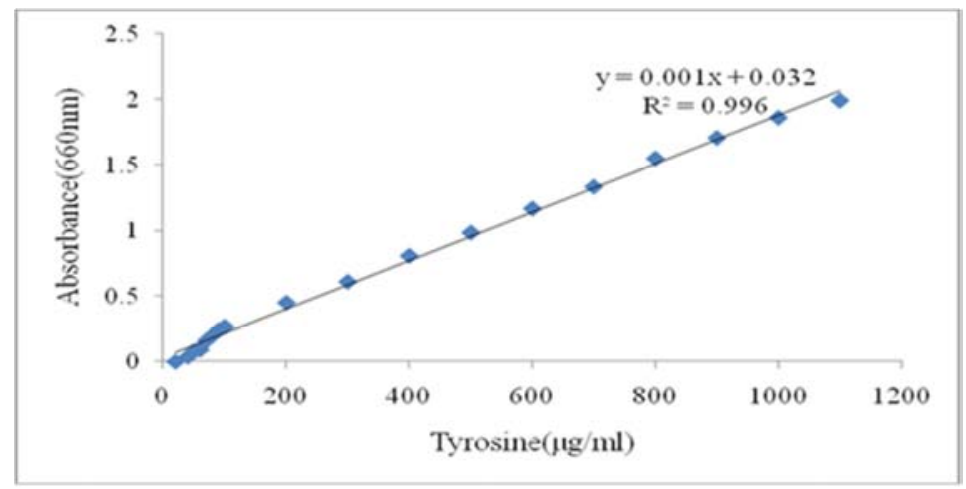

Figure 1. Tyrosine standard curve for determination of protease activity. 


\subsection{Optimization of Protease Production}

The optimum production time, temperature, and $\mathrm{pH}$ of the three selected isolates was found to be $36 \mathrm{~h}$ corresponding to protease activity of $9.6 \mathrm{U} / \mathrm{ml}$ for PI-3, $6.5 \mathrm{U} / \mathrm{ml}$ for PM-1 and $2.0 \mathrm{U} / \mathrm{ml}$ for PS-3, optimum temperature for PS-3 and PI-3 was found to be $40^{\circ} \mathrm{C}$, corresponding to protease activities of 13.2 and $9.7 \mathrm{U} / \mathrm{ml}$, respectively. Whereas, $37^{\circ} \mathrm{C}$ was the optimum for PM-1 $(3.2 \mathrm{U} / \mathrm{ml})$ and the optimum $\mathrm{pH}$ for protease production for the three isolates was 7 with protease activities for PS-3, PI-3 and PM-1 were $13.2 \mathrm{U} / \mathrm{ml}, 9.5 \mathrm{U} / \mathrm{ml}$ and $10.8 \mathrm{U} / \mathrm{ml}$, respectively. A gradual decrease in enzyme units was observed with increase in incubation period, clearly suggesting that the enzyme production is growth associated in nature $[22,26]$. In all three isolates, progressive decline of enzyme production was observed after their optimum temperatures and no enzyme production was observed beyond $50^{\circ} \mathrm{C}[21,22,6,23]$.

\subsubsection{Optimization of the Effect of $\mathrm{NaCl}$ Concentration on the Production of Protease}

Various $\mathrm{NaCl}$ concentrations (i.e. $0,0.2,0.4,0.6,0.8 \mathrm{M}$ ) were used to determine optimum level required for the production of protease by the three selected isolates (i.e. PS3, PI-3 and PM-1). It was observed that the growth medium containing $0.6 \mathrm{M}$ yielded the maximum activity in all isolates (26 U/ml, $17.4 \mathrm{U} / \mathrm{ml}$ and 46.3U/ml for PS-3, PM-1 and PI-3, respectively). This was followed by $0.4 \mathrm{M}$ of $\mathrm{NaCl}$ for isolates of PS-3 and PI-3 which resulted in activities of 19.4 $\mathrm{U} / \mathrm{ml}$ and $36.1 \mathrm{U} / \mathrm{ml}$, respectively. Whereas for isolate PM-1, $0.2 \mathrm{M}$ of $\mathrm{NaCl}$ resulted in the second highest protease activity (i.e. $13.2 \mathrm{U} / \mathrm{ml}$ ). It was also observed that in all isolates $0.8 \mathrm{M}$ $\mathrm{NaCl}$ concentration resulted in the least protease production (13.1, 8.0, and $27.7 \mathrm{U} / \mathrm{ml}$ in PS-3, PI-3 and PM-1, respectively).

\subsubsection{Effect of Metallic Ions on the Production of Protease}

The effect of metal ions on the production of protease by PS-3, PM-1 and PI-3 is optimize. The results showed that the presence of $\mathrm{Mn}^{2+}$ enhances production of protease by PS-3 and PM-1 while highest protease production by PI-3 was observed with the addition of $\mathrm{Mg}^{2+}$ in comparisons with the other metallic ions In previous reports, divalent metal ions such as $\mathrm{Ca}^{2+}$ were known to increase thermostability [24]. $\mathrm{Fe}^{2+}, \mathrm{Zn}^{2+}$ and $\mathrm{Cu}^{2+}$ had high inhibitory effect on the production of protease of the 3 isolates. $\mathrm{Zn}^{2+}$ showed the highest inhibitory effect followed by $\mathrm{Cu}^{2+}$. The toxic metal ions exert their toxicity by binding to a variety of organic ligands causing denaturation of proteins including enzymes. It was reported that $\mathrm{Ca}^{2+}, \mathrm{Mg}^{2+}$ and $\mathrm{Na}^{+}$ions enhanced the production of alkaline serine protease in Bacillus pumilus while $\mathrm{Cu}^{2+}$ and $\mathrm{Zn}^{2+}$ ions caused slight inhibition [25].

\subsection{Characterization of Protease}

\subsubsection{Effect of pH on the Stability of Proteases of the Selected Isolates}

The effect of $\mathrm{pH}$ on enzyme stability was examined by incubating the reaction mixture at $\mathrm{pH}$ values ranging from 5.0 to 10.0 and a temperature $37^{\circ} \mathrm{C}$ for 12 hours with casein in sodium phosphate buffer. The results showed that the stability of protease was higher at $\mathrm{pH}$ values ranging from 8.0 to 10.0 than at lower $\mathrm{pH}$ values exhibiting maximum stability at $\mathrm{pH} 9.0$ in PS-3 and PI-3; and at $\mathrm{pH} 8$ in PM-1 (Figure 2). These findings suggest that the proteases of the three isolates belonged to the alkaline protease class. In agreement with this, the optimum $\mathrm{pH}$ for stability of alkaline proteases from Bacillus spp. has been previously reported in various studies as lying between 9.0 and 11.0 [26, 27].

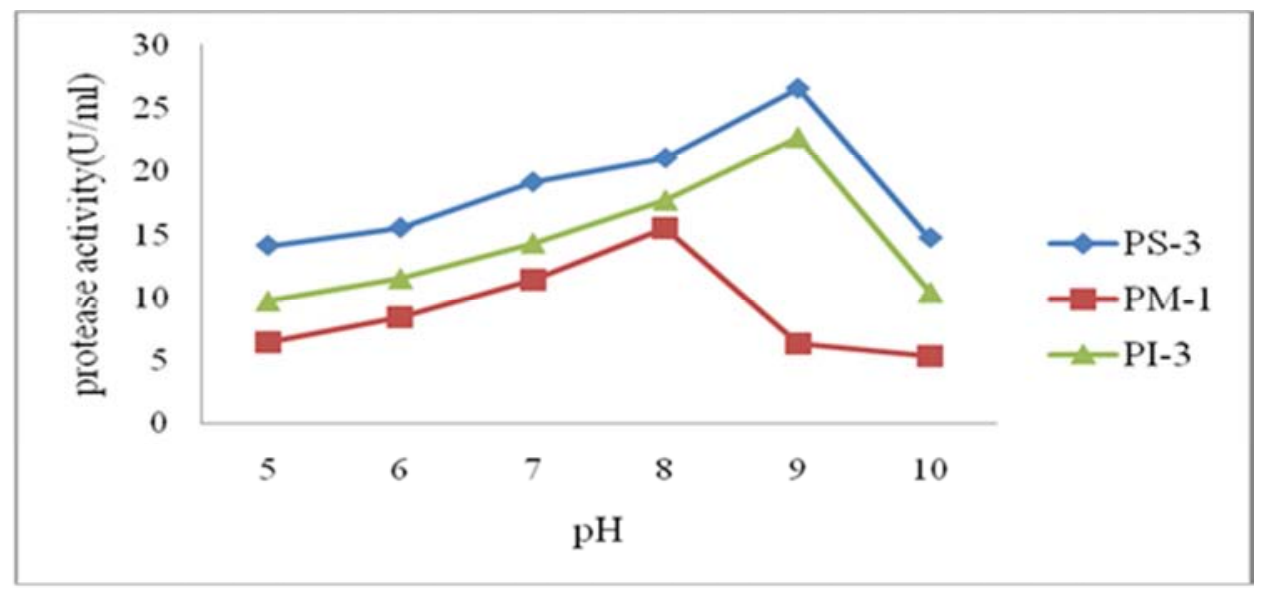

Figure 2. Effect of pH on stability of protease in PS-3, PI-3 and PM-1.

\subsubsection{Effect of Temperature on the Stability of Proteases of the Selected Isolates}

The effect of temperature on the stability of proteases was also measured by pre-incubating them at the optimum $\mathrm{pH}$ for $12 \mathrm{~h}$. The enzyme is active at temperatures between 30 and $80^{\circ} \mathrm{C}$, with a highest stability obtained when held at $75^{\circ} \mathrm{C}$ for PS-3 and PI-3 for $12 \mathrm{~h}$. However, the protease of PM- 1 showed maximum stability at $50^{\circ} \mathrm{C}$ with a similar incubation time. According to reports in stability of enzymes [21], the protease activity was relatively stable at temperatures ranging 
from $60-65^{\circ} \mathrm{C}$ and $85.2 \%$ of the activity was retained after incubation at $70^{\circ} \mathrm{C}$. The stability of protease enzyme could be due to the organisms' genetic adaptability to carry out their biological activities at higher temperatures [21].

\subsubsection{Effect of Divalent Ions on the Activities of Proteases}

The results showed that the proteases of all 3 isolates were activated by $\mathrm{Ca}^{2+}$ and $\mathrm{Mn}^{2+}$ at $1 \mathrm{mM}$ concentration and inhibited by these divalent metal ions at $5 \mathrm{mM}$ concentration (table 3 shows different concentration effects of each metallic ions among themselves). The optimum concentration of $\mathrm{Ca}^{2+}$ ions for maximum activity, however, varied among the protease enzymes [28]. Divalent metal ions such as $\mathrm{Ca}^{2+}$ are known to increase thermo-stability [24]. $\mathrm{Fe}^{2+}$ had little effect on the protease activity at $1 \mathrm{mM}$ concentration but inhibited the enzyme at $5 \mathrm{mM}$ concentration.

The other metal ions, i.e. $\mathrm{Zn}^{2+}$ and $\mathrm{Mg}^{2+}$, inhibited the protease activity towards casein at both 1 and $5 \mathrm{mM}$ concentrations and further increase in metal ion concentration increased inhibition. At $5 \mathrm{mM}$ concentration, $\mathrm{Mg}^{2+}$ showed the highest inhibitory effect followed by $\mathrm{Zn}^{2+}$. The toxic metal ions exert their toxicity by binding to a variety of organic ligands causing denaturation of proteins including enzymes. It was reported previously that $\mathrm{Ca}^{2+}$, $\mathrm{Mg}^{2+}$ and $\mathrm{Na}^{+}$ions enhanced the activity of alkaline serine protease from Bacillus pumilus, but $\mathrm{Cu}^{2+}$ and $\mathrm{Zn}^{2+}$ ions caused slight inhibition [25].

Table 3. Effects of physicochemical parameters on protease activity and stability.

\begin{tabular}{|c|c|c|c|c|c|c|}
\hline \multicolumn{7}{|c|}{ Effects of physicochemical parameters } \\
\hline \multirow[b]{2}{*}{ Parameter } & \multicolumn{2}{|l|}{ PS-3 } & \multicolumn{2}{|l|}{ PM-1 } & \multicolumn{2}{|l|}{ PI-3 } \\
\hline & $\begin{array}{l}\text { OD } 600 \mathrm{~nm} \text { /Average } \\
\text { value }\end{array}$ & $\begin{array}{l}\text { Protease activity } \\
\text { U/ml }\end{array}$ & $\begin{array}{l}\text { OD } 600 \mathrm{~nm} \\
\text { /Average value }\end{array}$ & $\begin{array}{l}\text { Protease activity } \\
\text { U/ml }\end{array}$ & $\begin{array}{l}\text { OD } 600 \mathrm{~nm} \\
\text { /Average value }\end{array}$ & $\begin{array}{l}\text { Protease activity } \\
\text { U/ml }\end{array}$ \\
\hline \multicolumn{7}{|c|}{ Effect of $\mathrm{pH}$ on protease stability } \\
\hline pH 5 & 0.255 & 14.1 & 0.123 & 6.4 & 0.178 & 9.7 \\
\hline pH 6 & 0.278 & 15.5 & 0.157 & 8.4 & 0.208 & 11.5 \\
\hline pH 7 & 0.335 & 19.1 & 0.206 & 11.4 & 0.255 & 14.3 \\
\hline $\mathrm{pH} 8$ & 0.365 & 21 & 0.275 & 15.5 & 0.311 & 17.7 \\
\hline $\mathrm{pH} 9$ & 0.454 & 26.5 & 0.122 & 6.3 & 0.395 & 22.7 \\
\hline $\mathrm{pH} 0$ & 0.265 & 14.7 & 0.105 & 5.3 & 0.189 & 10.4 \\
\hline \multicolumn{7}{|c|}{ Effect of Temperature on protease stability } \\
\hline $30^{\circ} \mathrm{C}$ & 0.233 & 12.7 & 0.206 & 11.4 & 0.453 & 26.2 \\
\hline $40^{\circ} \mathrm{C}$ & 0.358 & 20.5 & 0.258 & 14.5 & 0.552 & 32.2 \\
\hline $50^{\circ} \mathrm{C}$ & 0.455 & 26.6 & 0.400 & 23.1 & 0.567 & 33.1 \\
\hline $60^{\circ} \mathrm{C}$ & 0.536 & 31.2 & 0.226 & 12.6 & 0.624 & 36.5 \\
\hline $65^{\circ} \mathrm{C}$ & 0.567 & 33.1 & 0.191 & 10.5 & 0.716 & 42.1 \\
\hline $70^{\circ} \mathrm{C}$ & 0.587 & 34.3 & 0.177 & 9.6 & 0.725 & 42.6 \\
\hline $75^{\circ} \mathrm{C}$ & 0.601 & 33.4 & 0.135 & 7.1 & 0.756 & 44.4 \\
\hline $80^{\circ} \mathrm{C}$ & 0.330 & 18.8 & 0.089 & 4.3 & 0.352 & 20.2 \\
\hline \multicolumn{7}{|c|}{ Effect of Divalent ion at $1 \mathrm{mM}$ on protease activity } \\
\hline control & 1.107 & 67.4 & 0.978 & 57 & 1.067 & 63.2 \\
\hline $\mathrm{Ca}^{2+}$ & 0.582 & 34.5 & 0.425 & 24.7 & 1.121 & 62.4 \\
\hline $\mathrm{Mg}^{2+}$ & 0.085 & 4.1 & 0.105 & 5.3 & 0.086 & 4.2 \\
\hline $\mathrm{Mn}^{2+}$ & 0.305 & 17.3 & 0.401 & 23.1 & 0.175 & 9.5 \\
\hline $\mathrm{Fe}^{2+}$ & 0.279 & 15.8 & 0.122 & 6.3 & 0.445 & 28.5 \\
\hline $\mathrm{Zn}^{2+}$ & 0.169 & 8.7 & 0.098 & 4.3 & 0.101 & 5.1 \\
\hline \multicolumn{7}{|c|}{ Effect of Divalent ion at $5 \mathrm{mM}$ on protease activity } \\
\hline control & $0.977 \quad-12$ & 57.7 & 0.934 & 55.2 & 1.085 & 64.2 \\
\hline $\mathrm{Ca}^{2+}$ & 0.466 & 27 & 0.139 & 7.3 & 1.071 & 63.4 \\
\hline $\mathrm{Mg}^{2+}$ & 0.045 & 0.9 & 0.065 & 2.9 & 0.054 & 2.2 \\
\hline $\mathrm{Mn}^{2+}$ & 0.266 & 14.7 & 0.384 & 22.1 & 0.112 & 5.7 \\
\hline $\mathrm{Fe}^{2+}$ & 0.216 & 11.6 & 0.077 & 3.6 & 0.325 & 15.8 \\
\hline $\mathrm{Zn}^{2+}$ & 0.134 & 7.1 & 0.060 & 2.6 & 0.088 & 4.3 \\
\hline \multicolumn{7}{|c|}{ Evaluation of Agro-Industrial wastes for protease production } \\
\hline Nug cake & 0.219 & 1.2 & 0.202 & 1 & 0.435 & 2.5 \\
\hline Sesame cake & 0.327 & 2.1 & 0.248 & 1.3 & 0.490 & 2.8 \\
\hline Human Hair & 0.654 & 3.9 & 0.217 & 1.1 & 0.664 & 3.9 \\
\hline Wheat bran & 0.731 & 4.3 & 0.521 & 3 & 0.585 & 3.4 \\
\hline
\end{tabular}

\subsection{Evaluation of Some Agro-industrial Wastes as Substrate for Protease Production}

Evaluation of the agro-industrial wastes indicated that wheat bran was better than nug cake (niger seed cake) and sesame cake (sesame cake) for production of protease by all three isolates, whereas human hair was superior to $n u g$ cake and sesame cake only to isolate PS-3 and PI-3 (Figure 3).
Although microorganisms have a potential to produce enzymes, production cost of the enzyme is the critical issue for further application at industrial level. It is estimated that, growth media accounts for $30-40 \%$ of the production cost in enzyme industries [29]. For production of protease, agroindustrial wastes such as animal hairs removed from leather industries and barber shops; feathers from poultry industries, nug cake and sesame cake from agro-industries can serve as 
ideal substrates as they are cheap and readily available. Therefore, the feasibility of enzyme production on low cost fermentable substrates needs to be studied [30, 29, 31]. In addition, the removal of these non-degradable wastes could minimize environmental pollution.

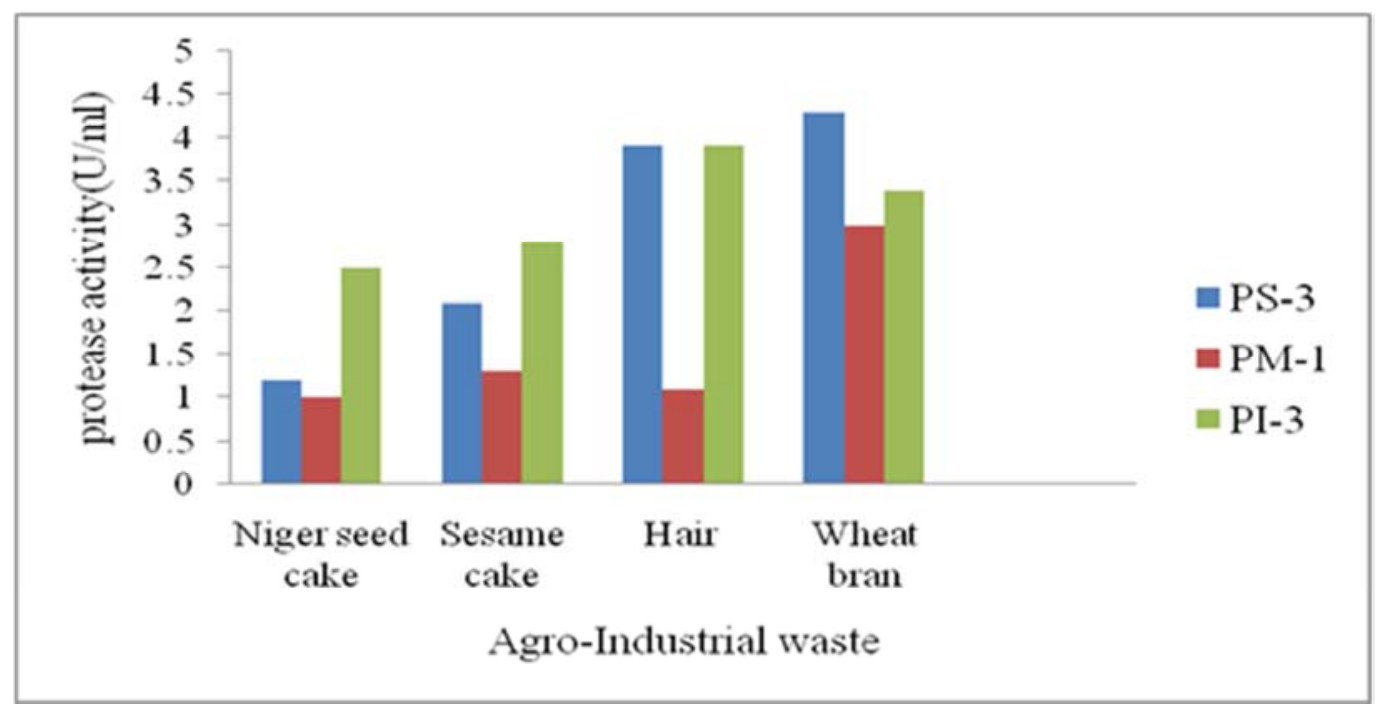

Figure 3. Protease production using agro-industrial wastes as substrate.

\section{Conclusion}

Proteases are one of the most important groups of industrial enzymes with considerable application in the animal feed processing, leather industry, medical activity, beverage industry and others sectors. In this study, protease was successfully produced by 3 bacterial isolates which were obtained from soil and agro-industrial wastes. On the basis of morphological and biochemical characteristics, these 3 isolates were identified to belong to genus Bacillus.

Although many potent isolates are on market for enzyme production, scientists prefer studying new isolates because they could be alternative for commercial use in many aspects. Many studies showed that researches will continue to isolate alternative strains for production of enzymes as well as proteases. The isolated new source of protease producing bacteria, from the soil and Agro- industrial waste sample reported in the present study may be alternative sources for the potential industrial applications. There are few reports in the literature on the production of proteases by Bacillus spp. using Agro-Industrial waste as substrates. Use of these substrates which are by product of Agro-Industry can efficiently be utilized for the commercial production of proteases and other valuable products.

\section{Abbreviations}

OD: Optical density

PM-1: Isolate from manure

PI-3: Isolate from industrial waste

PS-3: Isolate from soil

Rpm: revolutions per minute

TCA: trichloroacetic acid

SmF: Submerged fermentation

\section{References}

[1] Walsh, G. Proteins Biochemistry and Biotechnology. John Wiley \& Sons, Ltd., England. 2002; 547p.

[2] Whitford, D. Protein Structure and Function. John Wiley \& Sons, Ltd., England. 2005; 528p.

[3] Nadeem, M. Biotechnological production of alkaline protease for industrial use. PhD Thesis. University of Punjab, Lahore, Pakistan. 2009; 208p.

[4] Sumantha, A., C. Larroche and A. Pandey. Microbiology and Industrial Biotechnology of Food-Grade Proteases: A Perspective. Food Technol. Biotechnol. 2006; 44 (2): 211220.

[5] Nirmal, N. P., Shankar S. and Laxman R. S. Fungal Proteases: An Overview. J. Biotech and Biosci, 2011; 1 (1): 1-40.

[6] Sevinc, N. and E. Demirkan. Production of Protease by Bacillus sp. N-40 Isolated from Soil and Its Enzymatic Properties. J. Biol. Environ. Sci., 2011; 5 (14), 95-103

[7] Ikram. N. Enhanced production of thermostable bacterial proteases and their applications. $\mathrm{PhD}$. Thesis. University of Punjab. Pakistan. 2008; 158p

[8] Gupta, R., Q. K. Beg, S. Khan and B. Chauhan. An overview on fermentation, downstream processing and properties of microbial alkaline proteases. Appl Microbiol Biotechnol. 2002b; 60 (4): 381-95.

[9] Rao, M. B, Aparna T. M, Mohini G. S., Vasanti D. V. Molecular and biotechnological aspects of microbial proteases. Microbiol. Mol. Biol. Rev 1998; 62: 597-635.

[10] Genckal, H. and Tari, C. Alkaline protease production from alkalophilic Bacillus sp. isolated from natural habitats. Enzyme Microb. Technol., 2006; 39: 703-710. 
[11] Alnahdi, H. S. Isolation and screening of extracellular proteases produced by new Isolated Bacillus sp. Journal of Applied Pharmaceutical Science 2012; 2 (9): 071-074.

[12] Vishwanatha, T, Spoorthi N. J., Reena, V., Divyashree, B. C., Siddalingeshwara, K. G., Karthic, J and Sudipta K. M. Screening of Substrates for Protease Production from Bacillus licheniformisInternat. Journal of Engineering Science and Technology: 2010; 2(11): 6550-6554.

[13] Ghaemi. F. S, Tabandeh. F, Yakhchali. B and Eftekhar. F. Enhancement of alkaline protease production by Bacillus clausii using Taguchi experimental design. African Journal of Biotechnology. 2007; 6 (22): 2559-2564.

[14] Holt, J. G., N. R. Krieg, P. H. A. Sneath and J. T. Staley. Bergey's Manual of Determinative Bacteriology. Nineteenth edition, Williams and wilkins company, Baltimore, MD, USA, 1994; pp: 255-273.

[15] Hema, T. A and Shiny, M. Production of Protease Enzyme from Bacillus Clausii Sm3. IOSR Journal of Pharmacy and Biological Sciences. 2012; 1: 37-40

[16] Folin, O., and Ciocalteu, V. Enzymatic Assay of Protease Casein as a Substrate J. Biol. Chem. 1929; 73: 627

[17] Muthu, P. and Christudhas W. Purification and characterization of neutral protease enzyme from Bacillus Subtilis. J. Microbiol. Biotech. Res. 2012; 2 (4): 612-618

[18] Agrawal, R., Singh R., Verma A., Panwar P. and Verma A. K. Partial Purification and Characterization of Alkaline Protease from Bacillus sp. Isolated from Soil. World Journal of Agricultural Sciences. 2012; 8 (1): 129-133.

[19] Oliveira, A. N., Oliveira, L. A. and Andrade S. Production and Some Properties of Crude Alkaline Proteases of Indigenous Central Amazonian Rhizobia Strains. Brazilian Archives of Biology and Technology. 2010; 53: 1185-1195.

[20] Udandi B., Rajendran R., Palanivel K. Vinayaga S. and Manoharan M. Optimization of Protease Enzyme Production Using Bacillus Sp. isolated from different Wastes. Botany Research International 2009; 2 (2): 83-87.

[21] Al-Shehri, A.; Mostafa, M. and Yasser, S. Production and some properties of protease produced by Bacillus licheniformis isolated from Tihamet Asser, Saudi Arabia. Pak. J. Biol. Sci., 2004; 7, 1631-1635.
[22] Qadar, S. A. U., E. Shireen, S. Iqbal and A. Anwar. Optimization of Protease production from newly isolated strains of Bacillus sp. PCSIR EA-3. Indian Journal of Biotechnology 2009; 8: 286-290.

[23] Josephine S., Ramya V., Devi N., Ganapa B., Siddalingeshwara K. G., Venugopal. N and Vishwanatha T. Isolation, production and characterization of protease from Bacillus Sp isolated from soil sample. J. Microbiol. Biotech. Res., 2012; 2 (1): 163-168

[24] Rai SK, Roy JK, and Mukherjee AK. Characterization of a detergent-stable alkaline rotease from a novel thermophilic strain Paenibacillus tezpurensis sp. Nov. AS-S24-II. Appl. Micrbiol. Biotechnol. 2010; 85: 1437-1450.

[25] Huang, Q., Y. Peng, X. Li, H. Wang, and Y. Zhang. Purification and characterization of an extracellular alkaline serine protease with dehairing function from Bacillus pumilus. Curr. Microbiol. 2003; 46: 169-173.

[26] Deng, A., J. Wua, Y. Zhang, G. Zhang, T. Wena. Purification and characterization of a surfactant-stable high-alkaline protease from Bacillus sp. B001 Bioresource Technology 2010; 101: 7100-7106

[27] Kumara, M. S. Kashyap, N. S., Vijay. R., Rahul. T, Anuradha. M. Production and optimization of extra cellular Protease from bacillus sp. Isolated from soil. International Journal of Advanced Biotechnology and Research. 2012; 3: 564-569.

[28] Akel H, Al-Quadan F, Yousef TK. Characterization of a purified thermosatble protease from hyperthermophilic Bacillus strain HUTBS71. Eur. J. Sci. Res. 2009; 31: 280-288.

[29] Kumar, D. J. M. P. Venkatachalam, N. Govindarajan, M. D. Balakumaran and P. T. Kalaichelvan. Production and Purification of Alkaline Protease from Bacillus sp. MPTK 712 Isolated from Dairy Sludge. Global Veterinaria 2012; 8 (5): 433-439.

[30] Gessesse, A. The use of nug meal as a low-cost substrate for the production of alkaline protease by the alkaliphilic Bacillus sp. AR-009 and some properties of the enzyme" Bioresource Technology, 1997; 62: 59-61.

[31] Enshasy, E. H., Abuol-Enein, A., Helmy, S. and Azaly, E. Optimization of The industrial production of alkaline protease by Bacillus licheniformis in different production scales. Australian Journal of Basic and Applied Sciences. 2008; 2: 583-593. 